\title{
The Influence of Organization Factor on E-service Adoption: The Case of Cambodia
}

\author{
Seng Sokhea ${ }^{1 *} \quad$ Seoun Sophea ${ }^{2}$ \\ 1.PhD Student, College of Public Administration, Huazhong University of Science and Technology (Wuhan), \\ China \\ 2. PhD Student, School of Public Administration, China University of Geosciences (Wuhan), China
}

\begin{abstract}
Background: The diffusion of ICT has made the researchers or scholars in the field of e-government continue to find out the problems of pay attention on the government barriers to successfully implement it implement in public services in the both developed and developing countries. It is the important title for the top management leader in the public organization to reexamine and improve e-service for users. This paper is to illustrate examined factors of e-service adoption in public sector in Cambodia.

Method: Challenging factors which were proposed for as model of e-service adoption in study are the Top Management Support (TMS), and ICT skill (ICT-skill). 500 respondents who were civil servants (service providers) and general citizens (service recipients) participated in this study. The correlations and regression methods were employed in the IBM SPSS v.20. The study employed both online and face to face survey by which the determinants were examined in SPSS. The questionnaires were focused on the General Department of Tax (GDT) the Ministry of Commerce (MC), and the Ministry of Public Work and Transportation (MPWT).

Results: The majority of responses of participants were indicated that the determinants have the result as the following; TMS has strong direct effect and indirect effect to e-service adoption as H1 and H2. ICT-skill has strong direct effect on e-service adoption as $\mathrm{H} 3$. TMS has measure value as $\beta=.560, \mathrm{t}=16.20, \mathrm{P}=.000<0.01$ in direct effect influence on e-SA, and ICT-skill has measure value as $\beta=.831, \mathrm{t}=33.37, \mathrm{P}=.000<0.01$ in direct effect influence e-SA. The TMS value of indirect effect influence on e-SA is $\beta=.383, t=11.06, \mathrm{P}=.000$ $<0.01$

Conclusion: Regarding to rule of significant, it is seen that all determinants are the strongly predicting predicted variable which is highest strongly positive influenced on the e-service adoption (E-SA). All the hypotheses are confirmed by Pearson's correlation and Linear Regression test.
\end{abstract}

Keywords: Top management Support, ICT-skill, e-Service Adoption

DOI: $10.7176 / \mathrm{JETP} / 9-1-04$

\section{Introduction}

The diffusion of e-service in the public administration and private sectors has been adopted and improved rapidly worldwide; however, the adoption of the e-service among users has different levels due to their knowledge and trust (Hussein, Karim, Mohamed, \& Ahlan, 2007; McKnight, 2005; Sang, Lee, \& Lee, 2010). According to United Nation e-government Index, e-service is evaluated by three factors, including online service component, telecom infrastructure component, and human capital component (United Nations, 2016). Based on the evaluation of the online service component, telecom infrastructure component, and human capital component, this survey ranked 158 for the online service in Cambodia. $\mathrm{d}$ which is lower than its neighboring countries (United Nations, 2016).

The practice of e-service in public sectors in Cambodia has just started from the point of ICT development in the public organization that government created Government Administration Information System (GAIS) which has five flagship programs; an electronic approval system, real estate registration, resident registration, and vehicle registration, National homepage of Cambodia www.cambodia.org.kh (Bory Seng, 2008). Only some ministries provide e-services such as, Ministry of Economy and Finance (MEF) has provided online service three e-services, namely tax registration, tax return, and vehicle taxes (Kong, 2011) whereas Ministry of Commerce (MOC) has also provided the online business registration, (Sosak, 2016), and Ministry of Public Work and Transport has created application to provide driving lessons, , examination test, and online vehicle registration where the citizen can apply for vehicle registration number and driving license .

The problems of e-service adoption in public sector in Cambodia are related to both service providers and eservice users. The challenges of public e-services in Cambodia are not far different from other developing countries. The main barriers are the lack of ICT tools and human capital, and the Top Management Support. As the previous scholars, the top management support (TMS), and ICT skills (ICT-skill) (Oseni \& Dingley, 2014; Oseni, Dingley, \& Hart, 2016). Furthermore, the Royal Government has not developed clear guidelines that facilitate the systematic establishment of e-government services and the execution of its operations. Therefore, there is an urgent need to establish comprehensive and systemic plans for overcoming the limitations and barriers of e-government services in Cambodia (KOICA, 2014). 
Many scholars propose perceived ease of use, perceived usefulness, motivation, investment, experience, and usage frequency as the factors of e-government or e-service adoption (Carter \& Belanger, 2004; Mom Vireak, 2015; Sandhu \& Corbitt, 2002; Sang et al., 2010). While, Featherman \& Pavlou (2003) the proposed perceived risk (time risk, psychological risk, privacy risk, financial risk, performance risk, social risk, overall risk), perceived ease of use, and perceived usefulness influenced on e-service adoption (Featherman \& Pavlou, 2003). For this study, in order to solve the problems of e-service adoption in Cambodia, the Top Management Support and ICT skill will be proposed to investigate as the important roles which will be influenced on the e-service adoption in the case of Cambodia.

\section{Literature Review \\ 2.1 Concept of e-Service}

The concept of e-service (short for electronic service) represents one prominent application of utilizing the use of information and communication technologies (ICTs) in different areas which is a part of e-government. Eservice was contended that it was the self-service kind of marketplace environment which has already made more and more customers look for company access and customer support through the Internet (De Ruyter, Wetzels, \& Kleijnen, 2001; Featherman \& Pavlou, 2003). Both of them also suggested that e-services enable electronic communication, information gathering, transaction processing and data interchange within and between businesses across time and space (De Ruyter et al., 2001; Featherman \& Pavlou, 2003).There are many models of e-service adoption which proposed previous scholars. For instance, Three determinants were developed as model of e-service adoption which were Information quality, Systems quality, and Service Quality (Y.-C. Chen et al., 2017). Organizational Structure (Decision-Making Structure, Top Management Support, Goal alignment, Managerial IT Knowledge, Management Style and Resources Allocation) was influenced IS success dimension (information quality, System Quality, and Perceive Usefulness) (Hussein et al., 2007). Related to Alshehri \& Drew's review, there are several challenges and barriers that can delay progress of e-government implementation which is provided e-service for customers. Therefore, the challenge of e-government is also the challenge of e-service. This section, will briefly introduce the most important and common challenges and barriers based on literature review. The barrier of e-government was categorized four main e-government barriers; these are technical barriers, organizational barriers, social barriers, financial barriers. The four key terms were reviewed by many previous scholars (Alshehri \& Drew, 2010). These are described as the follow table1:

\begin{tabular}{|l|l|l|}
\hline \multicolumn{2}{|c|}{ Table 1: The Conceptual Barriers of e-Government or e-Service } \\
\hline No & Categories & Barriers \\
\hline 1 & Technical & ICT infrastructure, Privacy, and Security \\
\hline 2 & Organizational & $\begin{array}{l}\text { Top Management Support, Resistance to change to electronic way, Collaboration, Lack } \\
\text { of qualified, Personnel and Training }\end{array}$ \\
\hline 3 & Social & Digital Divided, Culture \\
\hline 4 & Financial & High Cost \\
\hline
\end{tabular}

\subsection{Organization structure}

The barrier of e-government implementation is not only pure technical factor as such ICT infrastructure, privacy and security, but also the organizational issue (Li, 2003). Organizational challenges include: Top management support, Resistance to change to electronic ways, Collaboration and Lack of qualified personnel and training as above review table1(Alshehri \& Drew, 2010). The review of organizational factor is the real situation of public e-service implementation in Cambodia. As such, the top management support and ICT-skill were reviewed by previous scholars as the following context.

\subsection{Top Management Support}

The role of top management appears to be crucial in achieving synergy between the activities and operations in the organization, because top management is an important source to achieve organizational goals. Top management is responsible of the understanding the organizational principles and values of its workers, in addition to generating synergy and compatibility between them (Manna, 2012; Turban \& Volonino, 2010). On the other side of information technology, the outstanding role played by the organizational structure became obvious in the success of the various organizations (C.-J. Chen, 2007). The influence of TMS was developed as the following model related to the organizational and information technology. This model was illustrated as the following figure1 (Parasuraman, Zeithaml, \& Berry, 1988). 


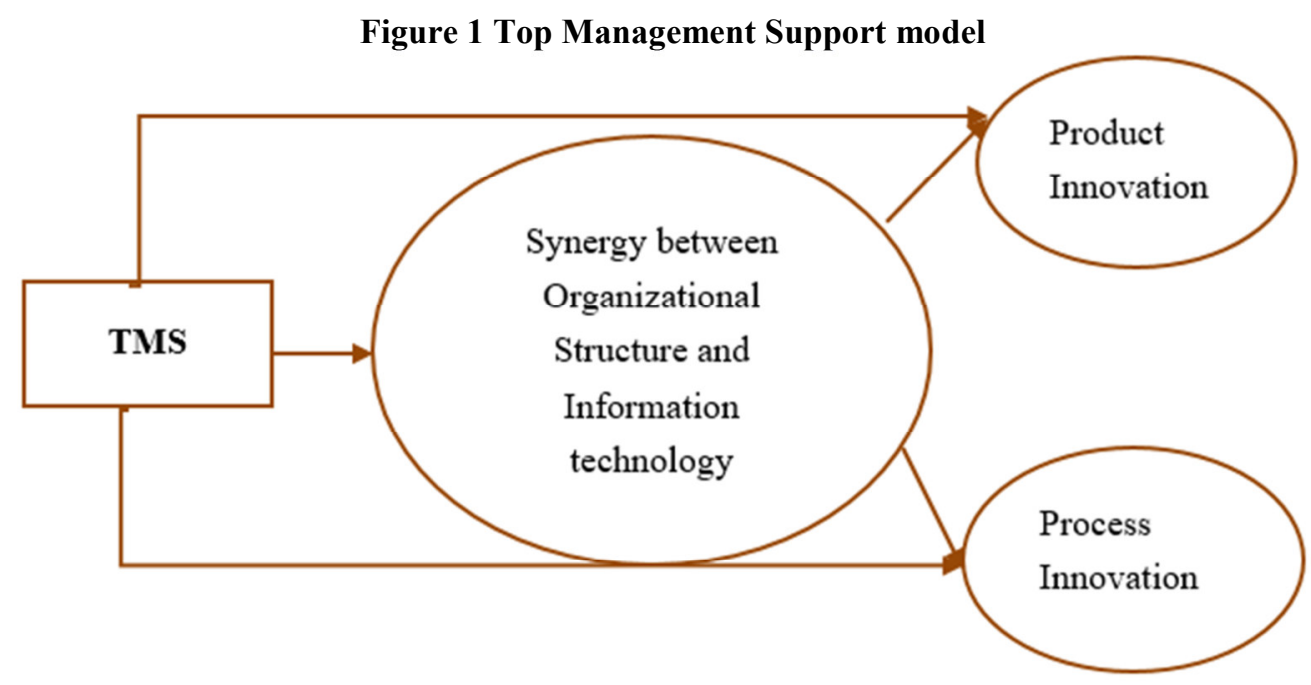

\subsection{ICT-Skill}

Although ICT skills are not affected on e-service in the developed countries, it is still very important to drive eservice adoption in the developing countries. The e-service increases the need for ICT-related skills in government and citizens. The skills required for e-government are not simply technical, as general managers also need broad skills to engage in the ICT decision-making process. Necessary skills include a basic technical understanding (IT literacy), but also an understanding of information management and the information society. Managers must be able to lead (and not be led by) the organization's IT department and outside partners, and must be able to integrate the organization's ICT strategy with its broader goals (Field, 2003). One of the main factors affecting the roll out and success of e-government in a country is the level of human capacity. The literacy of the users and the ability to use the computer are very important for e-government implementation. There are users who are illiterate (do not know how to read and write), who would need assistance. An example would be the elderly (senior citizens). Generally, senior citizens do not have much education and they would have to approach a customer service officer for assistance (Joseph, 2015). According to (Sun, Ku, \& Shih, 2015), they also mentioned e-literacy and digital divide are main challenges for transitioning to e-government. ELiteracy will reduce the digital divide and help the common man to participate in the exchange of ideas enabled by the social media (Morris, 2007). In additionally, (Altameem, Zairi, \& Alshawi, 2006), they inserted that Training is the focal element of current and prospective initiatives of e-government as well as, Norris (1999) posited that governments have often argued that their employees are not very well trained in using information technologies and this inadequate training result in resistance to change.

\section{Model Development and Hypotheses}

\subsection{Research Model}

As the theoretical framework, the top management support and ICT-skill were significant factors influenced on e-government or e-service by many scholars. The model development in this study is combination of determinants from previous scholars to develop as the extended model for the Cambodia situation for e-service implementation. Two independent variables are proposed to investigate as the important factor of e-service adoption. It is developed as the following figure.

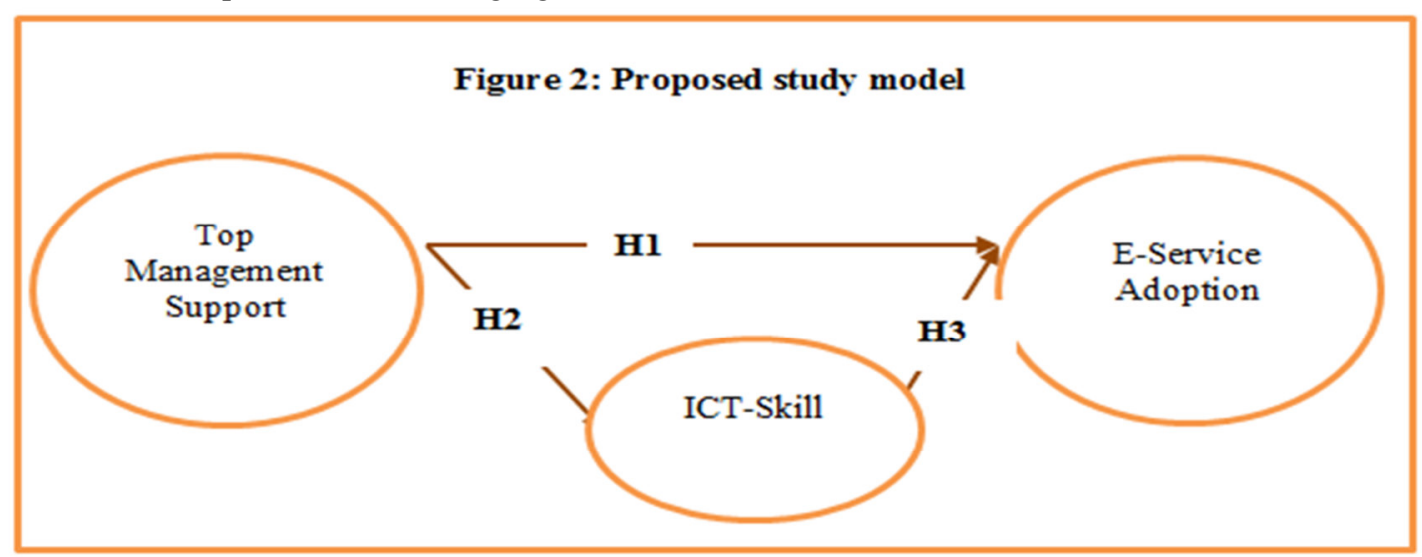




\subsection{Hypotheses}

Top Management support in this study refers to the encouragement, the instruction, guidelines, taking responsibility of the top management in order to provide the citizens and e-service providers to with ICT-skill or internet ability to serve the public e-service. Similarly, top management support is conceptualized as the involvement and participation of the executive or top-level management of the organization in IT/IS activities (Jarvenpaa \& Ives, 1991). TMS here is part of the organizational influence which refers government organizations themselves which play the important role to support the e-service users both public and private sectors (Alshehri \& Drew, 2010). Top Management support is also import factor to support e- service and this determinant was considered as barrier of acceptance to use ICT in public services. Moreover, King and Teo (1996) clearly point out that TMS facilitated the successful deployment of strategic IS application while the lack of TMS inhibited the strategic use IS. In order to achieve a successful project in civil agencies, it has to be endorsed by top management. Strong support from top management is important and is needed throughout the implementation (Altameem et al., 2006). The TMS was also tested to measure the e-government implementation by many scholars such as (Hussein et al., 2007), (Altameem et al., 2006), and the result was found that TMS was one of highest predictor of ICT usage which was influenced to e-government which is also included in eservice. Ideal top management shows a deep awareness of its followers needs, and provides an incentive, which is a source of encouragement and motivation for them to innovate and solve problems. Top management helps employees to address their needs for empowerment, improve personality, accomplish achievement, and enhance self-efficacy (Abrell, Rowold, Weibler, \& Moenninghoff, 2011; Jung, Chow, \& Wu, 2003; Layne \& Lee, 2001; Taylor, Russ-Eft, \& Taylor, 2009). As such, the above reasons and diffusion of ICT in Cambodia, the TMS will be developed as the following hypothesis (H1).

H1: Top management support is significantly and positively influenced on e-service adoption

As such, the review from previous scholars, the top management support also found that it is influenced on the synergy between the organization and information technology (Al Shaar, Khattab, Alkaied, \& Manna, 2015). Many studies that examined the relationship between top management and innovation indicated that top management positively affects innovation, and that there is a positive relationship between innovation and performance of organizations (Bowen, Rostami, \& Steel, 2010; Ryan \& Tipu, 2013). According to (Al Shaar et al., 2015), he proposed the model of TMS which is influence on organizational structure, product innovation, and process innovation. The results indicated the presence of the effect of top management support in achieving synergy between the organizational structure and information technology. On the other hand, the TSM is very potential to motivate their own officer to use the IT or ICT and including e-service. Therefore, the top leaders also have important roles to motivate the employee in organization to provide the ICT or internet- skill to the eservice providers and users. As such, the explaining the relationship between TMS and organizational, It will be developed the hypothesis (H2) for e-service adoption as the following.

H2: Top management support is significantly and positively influenced on ICT-skill

ICT-skill in this study refers to the ability citizens and e-service providers to use the multiple of ICTs programs, such as internet skill, computer office, website system, social media any relevant ICT tools and so on. ICT skill is also the important determinant factor the e-service implementation, especially in the developing country. For instance, low ICT literacy rate is a serious impediment for the adoption of e-government in Nigeria as it hampers both the appreciation and appropriation of e-government services. In order for citizens to maximize the full benefits of e-government, beyond knowing how to read and write they also need to possess basic ICT literacy (Omeire \& Omeire, 2014). Many scholars reviewed that the ICT- skill was also the important barriers of egovernment and e-service adoption (Field, 2003) (Ndou, 2004). Therefore, this study needs the ICT skill to investigate as the determinant of e-service adoption for the case of Cambodia. It is determined the hypothesis (H3) which will develop as the following.

H3: ICT-skill is significantly and positively influenced on e-service adoption

\section{Research Methodology}

\subsection{Simple Design and Data Collection}

The quantitative data analysis was studied to investigate the e-service adoption in Cambodia. The questionnaires are delivered to 500 participants who are to mark the score of each variable; they are citizens (general e-users) and civil servant from three public organizations (Ministry of Commerce, Ministry of Public Work and Transportation, and General Department of Tax). This study aimed to identify the direct effect of top management support on e-service adoption and indirect effect through ICT-skill on e-service adoption in Cambodia. This study is the deductive approach that emphasizes the universal law of cause and effect on explanatory framework which assumes a realistic ontology which is that the reality consists of a world of objectively defined the fact (Ali \& Birley, 1999). The research is the modification of theory by using the relevant method to test the hypotheses proposed. The data is collected by designed by 5 levels of the likert scale questions which are categorized from $1=$ strong disagree to $5=$ strong agree. Likert-scale items are useful for 
gathering respondents' feelings, opinions, attitudes, etc. on any language-related topics (Brown, 2000).

\subsection{Data analysis}

In order to measure the relationship between dependent and independent variable, the Pearson's Bivariate Correlation and Linear Regression will be used to investigate the model of e-service adoption. The reliability will be also tested the consistent of each variable. Cronbach's alpha is a commonly used measure of reliability of a set of two or more construct indicators. Reliability is a measure of internal consistency of the construct indicators(Streiner, 2003).

\section{Result and Discussion}

\subsection{Pearson's Correlations Matrix}

The Pearson correlation coefficient, also known as the product moment correlation coefficient, is represented in a sample by $r$, while in the population from which the sample was drawn it is represented by $p$. The coefficient is measured on a scale with no units and can take a value from -1 through 0 to +1 (Sedgwick, 2012). The significance of $\mathrm{P}$ values on graphs, investigators commonly use a "Michelin Guide" scale. *: $\mathrm{P}<0.05$ (significant), **: $\mathrm{P}<0.01$ (highly significant); ***: $\mathrm{P}<0.001$ (extremely significant) which are generally accepted conventional level with a confidential interval of 95\% (Graphpad, 2000). In this case, the table 2 indicates that all the variables are positive highly significant to the e-service adoption (E-SA). As the result, TMS has mean score 2.43 with $\mathrm{r}=848^{* *} \mathrm{P}<0.01$, ICT-skill has mean score 2.63 with $\mathrm{r}=848^{* *} \mathrm{P}<0.01$.This is clearly indicated that the TMS and ICT-skill have strong relationship with e-Service Adoption.

\begin{tabular}{|l|l|l|l|l|l|}
\hline \multicolumn{7}{|c|}{ Table 2: Pearson's Correlations Matrix } \\
\hline \multirow{2}{*}{ TMS } & TMS & ICT-skill & e-Service Adoption & Mean Score & St. Deviation \\
\hline \multirow{2}{*}{ ICT-skill } & 1 & & & \multirow{2}{*}{2.43} & \multirow{2}{*}{1.39} \\
\cline { 2 - 6 } & Sig. & & & \multirow{2}{*}{2.63} & \multirow{2}{*}{1.38} \\
\hline \multirow{2}{*}{ e-Service Adoption } & $.831^{* *}$ & 1 & & \multirow{2}{*}{2.55} & \multirow{2}{*}{1.38} \\
\cline { 2 - 5 }$*$ Sig. & $.878^{* *}$ & $.848^{* *}$ & 1 & .000 & \\
\cline { 2 - 4 } & Sig. Correlation is significant at the 0.01 level (2-tailed). N=500 & .000 & & \\
\hline
\end{tabular}

\subsection{Structure Equation Model (SEM)}

The SEM of this paper is referred to the independent variable (X) and dependent variable (Y). Linear Regression can analyze only one linkage between independent and dependent variable at a time (Gerbing \& Anderson, 1988). According to this research model, TMS and ICT-skill are independent variable (IV) between and eService Adoption is dependent variable (DV) but ICT-skill also has the role of mediator. In this case, Linear Regression is tested two times: Firstly, the linear regression between IV (TMS and ICT-skill) and e-service Adoption (DV) is tested. Secondly, the linear regression between IV (TMS) and DV (ICT-skill) is tested. The result of Linear Regression is illustrated as the following tables:

Table 3: It is indicated that H1 Top management Support (TMS) has measure value as $\beta=.560, t=16.20, P$ $=.000<0.01$. The H3 shows that ICT-skill has measure value as $\beta=.383, \mathrm{t}=11.06, \mathrm{P}=.000<0.01$. These are indicated that all of hypotheses predicted $(\mathrm{H} 1$, and $\mathrm{H} 3)$ are strongly positive influenced on e-service adoption, but H1 (TMS) which is direct highest positive influenced on the e-service adoption (e-SA). The hypotheses (H3) are also indirect high positive influenced on the e-service adoption (E-SA) through mediator ICT-skill.

Table 4: It is indicated that $\mathrm{H} 2$ (ICT-skill) has value as $\beta=.831, \mathrm{t}=33.37, \mathrm{P}=.000<0.01$. This means that it is direct effect and the highest positive influenced on e-Service Adoption.

Table 3: Result of Hypotheses Testing

\begin{tabular}{clllll}
\hline Hypotheses & Relationship (IV and DV) & Coefficient $(\boldsymbol{\beta})$ & T -value & Sig. (P-value) & Support \\
\hline H1 & TMS $\rightarrow$ e-SA & .560 & 16.202 & .000 & Confirm \\
H3 & ICT $\rightarrow$ e-SA & .383 & 11.064 & .000 & Confirm \\
\hline
\end{tabular}

Dependent Variable: e-Service Adoption

Table 4: Result of Hypotheses Testing

\begin{tabular}{|c|c|c|c|c|c|}
\hline Hypotheses & Relationship (IV and DV) & Coefficient $(\beta)$ & T -value & Sig. (P-value) & Support \\
\hline H2 & TMS $\rightarrow$ ICT - skill & .831 & 33.379 & .000 & Confirm \\
\hline
\end{tabular}

Dependent Variable: ICT-skill 
Figure 3: Result of Structural Equation Model

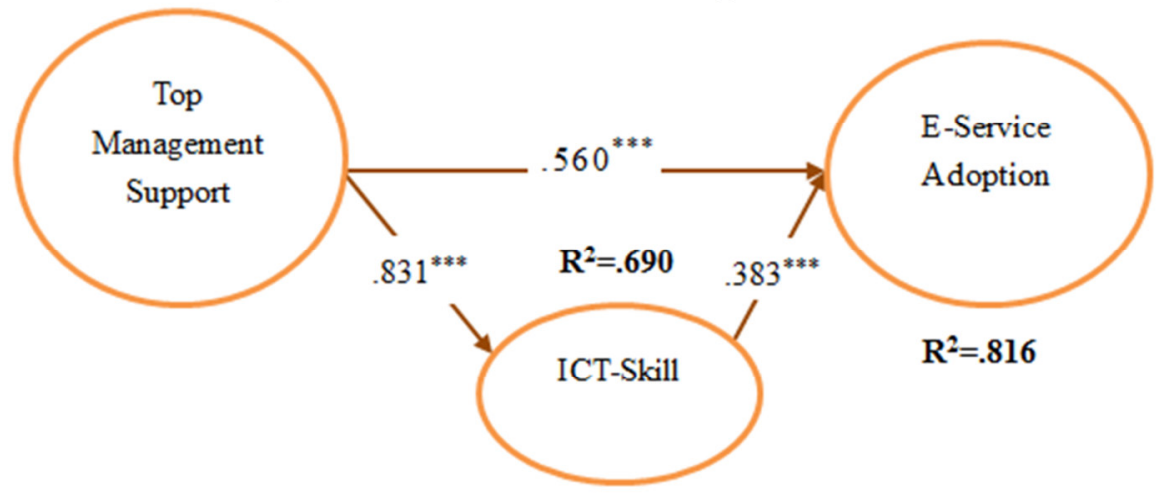

\subsection{Reliability Test}

The research instrument is tested to found out the reliable data for measurement this research model. According to the statistic rule, the majority of individuals correctly reported Cronbach's alpha as the measure of internal consistency reliability, but then opted to conduct data analysis using individual items (Gliem \& Gliem, 2003). The following rules of thumb was provided " $\geq .9$ - Excellent, $\geq .8$ - Good, $\geq .7$ - Acceptable, $\geq .6-$ Questionable, $\geq .5$ - Poor, and $\geq .5$ - Unacceptable" (George \& Mallery, 2003). AS the result, the table 5 is indicated that the value of Alpha for each determinant $(\mathrm{TMS}=.918$, ICT-skill $=.935$, and e-SA $=.908)$ and table 6 is indicated that the total of three variable value of Alpha is 946. It is shown the excellent reliability and the data collected by questionnaire are believable of $94 \%$ of participants 'responses.

\begin{tabular}{lcc}
\hline \multicolumn{3}{l}{ Table 5 Reliability for each Variable } \\
\hline Construct & Items & Cronbach's Alpha \\
\hline TMS & 4 & .918 \\
ICT-skill & 3 & .935 \\
e-SA & 4 & .908 \\
\hline
\end{tabular}

Table 6: Reliability total of variable

\begin{tabular}{|c|c|c|}
\hline Cronbach's Alpha & Cronbach's Alpha & N of Items \\
\hline .946 & .946 & 3 \\
\hline
\end{tabular}

\section{Conclusion, Recommendation and future research}

In conclusion, regarding to this study, it is found that the weakness of e-service using in public sector is illustrated by above research model. All of variables proposed which are TMS and ICT-skill are qualified as the weakness of e-service implementation in the case of Cambodia, but they have different level influence on eservice adoption. TMS has direct effect positive influence on e-SA and it also has indirect effect positive influenced on e-SA through ICT-skill as the mediator. ICT-skill has the highest direct effect positive influenced on e-SA. It is indicated as the following value that TMS has measure value as $\beta=.560, \mathrm{t}=16.20, \mathrm{P}=.000<$ 0.01 in direct effect influence on e-SA, and ICT-skill has measure value as $\beta=.831, \mathrm{t}=33.37, \mathrm{P}=.000<0.01$ in direct effect influence e-SA. The TMS value of indirect effect influence on e-SA is $\beta=.383, \mathrm{t}=11.06, \mathrm{P}=.000$ $<0.01$. As the result scrutinized above, the driving of e-service adoption need to improve the TMS, and Skill for participants by the e-service provider or government agency, and ICT training for participants is also the most important for e-service adoption in Cambodia.

During survey, it was felt that e-service adoption for the case of Cambodia is flawed. To address this urgent need improved e-service in the public sector is compiled through observations, group discussions, newspapers and interview with top leaders of organizational government. To improve the e-service implementation of Cambodia, the government or top management leaders have the important roles to improve all of the determinant factors which have been found in this study as the following suggestions.

1. Top management support is important roles to encourage his or her staff to deliver the information, relevant documents, or announcements for public through government institutions website by timeliness and accuracy. Regarding to the group of the citizens responses, the result was found that the mean score of measurement of the top management supports is 2.43. It is shown the weakness of the lop leaders to support the public e-service in Cambodia. Therefore, the top leaders in governmental instructions have to courage the citizens and e-service providers to use e-services. On the other hand, the policy making related to e-services should be clear to announce with responsibility. For example, the top leaders set 
regulations or actions plans to promote the e-service implementation, they have to check and follow up what they proposed in order to insure the staff's activities.

2. ICT skill in this study is also the main problems for Cambodia situation, the most the citizens lack of ability to ICT such as computers, smartphones, email, social media, and information on internet and so on. According to the survey for the group of citizens 'respondents, value mean score of ICT is 2.63, it is illustrated the weakness of ability to use it for e-service implementation. In order deal with these problems, the top leaders have to train the citizens how to use the Internet, the systems, register procedures and ICT skill. Regarding to my opinion, I expect that the citizens have enough ability to ICT skill related to e-service, they will accept to use it.

The limitation of future research, these factors of e-service adoption as the determinant of management support (TMS) and ICT-skill may investigate again to predict the variable factors of e-service adoption because these variables are just the contribution idea only, so that it maybe not sufficient to synthesize the real proof for e-service adoption. In contrary, the next scholars may also develop this model by adding or reducing the necessary determinants which she or he think that it is better to improve the e-service implementation for Cambodia situation. Briefly, for future research for next scholars, they can propose TMS and ICT-skill or add some related variables to investigate again or to develop as the model for their distribution conceptual framework, because it maybe will be change the behaviour of the top leader through the diffusion of information technology.

\section{Acknowledgement}

This research is encouraged by Professor Zhang Yi in the College of Public Administration (HUST) and sponsored by Chinese Government Scholarship. It would not be achieved if it has not his comment and support. On the other hand, it is also participated with the respondents both civil servant and citizens as e-service users in Cambodia.

\section{References}

Abrell, C., Rowold, J., Weibler, J., \& Moenninghoff, M. (2011). Evaluation of a long-term transformational leadership development program. German Journal of Human Resource Management, 25(3), 205-224.

Al Shaar, E. M., Khattab, S. A., Alkaied, R. N., \& Manna, A. Q. (2015). The effect of top management support on innovation: The mediating role of synergy between organizational structure and information technology. International Review of Management and Business Research, 4(2), 499.

Ali, H., \& Birley, S. (1999). Integrating deductive and inductive approaches in a study of new ventures and customer perceived risk. Qualitative market research: an international journal, 2(2), 103-110.

Alshehri, M. A., \& Drew, S. (2010). Implementation of e-government: advantages and challenges.

Altameem, T., Zairi, M., \& Alshawi, S. (2006). Critical success factors of e-government: A proposed model for e-government implementation. Paper presented at the Innovations in Information Technology, 2006.

Bory Seng. (2008). National ICT Policy of Cambodia \& E-Government. Paper presented at the Capacitybuilding Workshop on Back Office Management

for E/M-Government in Asia and the Pacific Region, Shanghai, People Republic of China.

Bowen, F. E., Rostami, M., \& Steel, P. (2010). Timing is everything: A meta-analysis of the relationships between organizational performance and innovation. Journal of Business Research, 63(11), 1179-1185.

Brown, J. D. (2000). What issues affect Likert-scale questionnaire formats. Shiken: JALT Testing \& Evaluation SIG Newsletter, 4(1).

Carter, L., \& Belanger, F. (2004). The influence of perceived characteristics of innovating on e-government adoption. Electronic Journal of e-Government, 2(1), 11-20.

Chen, C.-J. (2007). Information technology, organizational structure, and new product development---the mediating effect of cross-functional team interaction. IEEE Transactions on Engineering Management, 54(4), 687-698

Chen, Y.-C., Chen, Y.-C., Shen, Y.-C., Shen, Y.-C., Lee, C. T.-Y., Lee, C. T.-Y., . . Yu, F.-K. (2017). Measuring quality variations in e-service. Journal of Service Theory and Practice, 27(2), 427-452.

De Ruyter, K., Wetzels, M., \& Kleijnen, M. (2001). Customer adoption of e-service: an experimental study. International journal of service industry management, 12(2), 184-207.

Featherman, M. S., \& Pavlou, P. A. (2003). Predicting e-services adoption: a perceived risk facets perspective. International journal of human-computer studies, 59(4), 451-474.

Field, T. (2003). OECD E-Government Studies The E-Government Imperative: OECD Publishing.

George, D., \& Mallery, P. (2003). SPSS for Windows Step by Step: A Simple Guide and Reference Fourth Edition (11.0 update): Answers to Selected Exercises: Boston, MA: Allyn \& Bacon.

Gerbing, D. W., \& Anderson, J. C. (1988). An updated paradigm for scale development incorporating unidimensionality and its assessment. Journal of marketing research, 186-192. 
Gliem, J. A., \& Gliem, R. R. (2003). Calculating, interpreting, and reporting Cronbach's alpha reliability coefficient for Likert-type scales.

Graphpad. (2000). Intuitive Biostatistics: Interpreting Nonsignificant P values. Copyright (c) 1995 by Oxford University Press Inc.

Hussein, R., Karim, N. S. A., Mohamed, N., \& Ahlan, A. R. (2007). The influence of organizational factors on information systems success in e-government agencies in Malaysia. The electronic journal of information systems in developing countries, 29.

Jarvenpaa, S. L., \& Ives, B. (1991). Executive involvement and participation in the management of information technology. MIS quarterly, 205-227.

Joseph, S. R. (2015). Success factors influencing e-government implementation. International Journal of Marketing and Technology, 5(1), 127.

Jung, D. I., Chow, C., \& Wu, A. (2003). The role of transformational leadership in enhancing organizational innovation: Hypotheses and some preliminary findings. The Leadership Quarterly, 14(4), 525-544.

King, W. R., \& Teo, T. S. (1996). Key dimensions of facilitators and inhibitors for the strategic use of information technology. Journal of Management Information Systems, 12(4), 35-53.

KOICA. (2014). Cambodian ICT Masterplan 2020. Korean International Cooperation Agency

Kong, V. (2011). Gerneral Department of Taxation of Ministry of Economy and Finance in Cambodia. In C. TV (Ed.), Tax colletion.

Layne, K., \& Lee, J. (2001). Developing fully functional E-government: A four stage model. Government Information Quarterly, 18(2), 122-136.

Li, F. (2003). Implementing E-Government strategy in Scotland: current situation and emerging issues. Journal of Electronic Commerce in Organizations (JECO), 1(2), 44-65.

Manna, A. (2012). Evaluation of the role of top management in achieving synergy between organizational structure and information technology in communications and banking sectors. Doctoral theses, Amman Arab University, Jordan.

McKnight, D. H. (2005). Trust in information technology. The Blackwell encyclopedia of management, 7, 329331.

Mom Vireak, H. S. (2015). Investigation Factors of E-government Adoption in Cambodia. ISSTE, 5, 78-81.

Morris, A. (2007). E-literacy and the grey digital divide: a review with recommendations. Journal of information literacy, 1(3), 13-28.

Ndou, V. (2004). A. Carvin, J. Hill, and S. Smothers, E-government for all. The electronic journal of information systems in developing countries, 18.

Norris, D. F. (1999). Leading edge information technologies and their adoption: Lessons from US cities Information technology and computer applications in public administration: Issues and trends (pp. 137156): IGI Global.

Omeire, E. U., \& Omeire, C. (2014). New wine in old wine skin: an exploration of major constraints to egovernment implementation in Nigeria.

Oseni, K., \& Dingley, K. (2014). Challenges of e-service adoption and implementation in Nigeria: lessons from Asia. International Journal of Social, Behavioral, Educational, Economic, Business and Industrial Engineering, 8(12), 3956-3963.

Oseni, K., Dingley, K., \& Hart, P. (2016). Barriers facing e-Service technology in developing countries: a structured literature review with Nigeria as a case study. Paper presented at the 2015 International Conference on Information Society (i-Society).

Parasuraman, A., Zeithaml, V. A., \& Berry, L. L. (1988). Servqual: A multiple-item scale for measuring consumer perc. Journal of retailing, 64(1), 12.

Ryan, J. C., \& Tipu, S. A. (2013). Leadership effects on innovation propensity: A two-factor full range leadership model. Journal of Business Research, 66(10), 2116-2129.

Sandhu, K., \& Corbitt, B. J. (2002). Assessing web-based electronic services adoption model (E-SAM): Deakin University School of Information Systems.

Sang, S., Lee, J.-D., \& Lee, J. (2010). E-government adoption in Cambodia: a partial least squares approach. Transforming Government: People, Process and Policy, 4(2), 138-157.

Sedgwick, P. (2012). Pearson's correlation coefficient. BMJ: British Medical Journal (Online), 345

Sosak, P. (2016). Declaration of Online Bussiness Registration Ministry of Commerce. from www.businessregistration.moc.gov.kh/laws-and-regulations/prakas/

Streiner, D. L. (2003). Being inconsistent about consistency: When coefficient alpha does and doesn't matter. Journal of personality assessment, 80(3), 217-222.

Sun, P.-L., Ku, C.-Y., \& Shih, D.-H. (2015). An implementation framework for E-Government 2.0. Telematics and Informatics, 32(3), 504-520.

Taylor, P. J., Russ-Eft, D. F., \& Taylor, H. (2009). Transfer of management training from alternative perspectives: 
American Psychological Association.

Turban, E., \& Volonino, L. (2010). Information technology for management transforming organizations in the digital economy . Hoboken, NJ: Jon Wiley and Son: Inc.

United Nations. (2016). UNITED NATIONS E-GOVERNMENT SURVEY 2016. New York, : Department of Economic and Social Affairs.

\begin{tabular}{|c|c|c|c|c|c|c|}
\hline \multirow{3}{*}{ 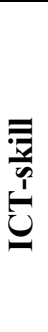 } & $\begin{array}{l}\text { 30. I am able to create e-mail or social media when I need to deliver } \\
\text { information and documents to my colleagues or government agencies }\end{array}$ & 1 & 2 & 3 & 4 & 5 \\
\hline & $\begin{array}{l}\text { 31. I am able to use computer to write or complete my job relevance or } \\
\text { online registration. }\end{array}$ & 1 & 2 & 3 & 4 & 5 \\
\hline & $\begin{array}{l}\text { 32. I am able to use smartphones to download the applications which are } \\
\text { provided by government agencies }\end{array}$ & 1 & 2 & 3 & 4 & 5 \\
\hline \multirow{4}{*}{$\sum_{i=1}^{\infty}$} & $\begin{array}{l}\text { 33. I used to get the instruction how to use the e-service application } \\
\text { system from my top manager }\end{array}$ & 1 & 2 & 3 & 4 & 5 \\
\hline & $\begin{array}{l}\text { 34. My top manger always encourages me to use the online service to ask } \\
\text { for many kinds of my services. }\end{array}$ & 1 & 2 & 3 & 4 & 5 \\
\hline & $\begin{array}{l}\text { 35. My top manager often tell me to take responsibility for e-service } \\
\text { which is proposed by the citizens }\end{array}$ & 1 & 2 & 3 & 4 & 5 \\
\hline & $\begin{array}{l}\text { 36. When I ask for the information to my manager trough online, he or } \\
\text { she satisfies to provide it to me. }\end{array}$ & 1 & 2 & 3 & 4 & 5 \\
\hline \multirow{4}{*}{ 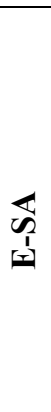 } & $\begin{array}{l}\text { 37. I adopt e-Service because the TMS encourage me to use it deliver the } \\
\text { relevant information or document. }\end{array}$ & 1 & 2 & 3 & 4 & 5 \\
\hline & $\begin{array}{l}\text { 38. I adopt e-Service in Cambodia because the TMS satisfy to give me } \\
\text { clear instruction }\end{array}$ & 1 & 2 & 3 & 4 & 5 \\
\hline & $\begin{array}{l}\text { 39. I adopt e-Service in Cambodia because I know to use internet, or } \\
\text { relevant website. }\end{array}$ & 1 & 2 & 3 & 4 & 5 \\
\hline & 40. I adopt e-Service in Cambodia, because I have enough ICT skill. & 1 & 2 & 3 & 4 & 5 \\
\hline
\end{tabular}

